\title{
The Krüppel-like factors in female reproductive system pathologies
}

\author{
Rosalia C M Simmen, Melissa E Heard, Angela M Simmen', Maria Theresa M Montales, \\ Meera Marji, Samantha Scanlon and John Mark P Pabona ${ }^{2}$ \\ Department of Physiology and Biophysics, University of Arkansas for Medical Sciences, Little Rock, \\ Arkansas 72205, USA \\ ${ }^{1}$ Department of Obstetrics and Gynecology, University of Michigan Health System, Ann Arbor, Michigan 48109, USA \\ ${ }^{2}$ Department of Internal Medicine, Harlem Hospital Center, Columbia University Medical Center, \\ New York, New York 10037, USA
}

Correspondence should be addressed to R C M Simmen

Email

simmenrosalia@uams.edu

\begin{abstract}
Female reproductive tract pathologies arise largely from dysregulation of estrogen and progesterone receptor signaling, leading to aberrant cell proliferation, survival, and differentiation. The signaling pathways orchestrated by these nuclear receptors are complex, require the participation of many nuclear proteins serving as key binding partners or targets, and involve a range of paracrine and autocrine regulatory circuits. The members of the Krüppel-like factor (KLF) family of transcription factors are ubiquitously expressed in reproductive tissues and have been increasingly implicated as critical co-regulators and integrators of steroid hormone actions. Herein, we explore the involvement of KLF family members in uterine pathology, describe their currently known molecular mechanisms, and discuss their potential as targets for therapeutic intervention.
\end{abstract} Key Words - KLF

- endometrial pathologies

- progesterone

- Notch

- Wnt

Journal of Molecular Endocrinology (2015) 54, R89-R101

\section{Introduction}

The human uterus has a unique role in the successful transmission of germ line DNA to guarantee the propagation of the human species. Biologically, it is destined to provide the fertilized egg with a 'nurturing' environment for its development and maturation into a complex entity with unique capabilities to eventually function on its own. Defects in the proper development and function of the uterus present a major hurdle to reproduction. Moreover, various uterine-related pathologies, including endometrial and cervical carcinoma, endometriosis, and leiomyoma, may arise post-puberty to further contribute to infertility. The steroid hormones estrogen and progesterone, working through their cognate nuclear receptors (estrogen receptor 1 (ESR1) and ESR2; progesterone receptor A (PGRA) and PGRB isoforms) are major regulators of uterine development and function (Kim et al. 2013, Hamilton et al. 2014). Their multi-faceted transcriptional pathways involve interactions with numerous nuclear co-regulators (Dasgupta \& O'Malley 2014) and result in altered levels of signaling molecules that act through paracrine and autocrine circuits. The elucidation of the underlying mechanism(s) for the autonomous and collective behavior of the multiple cell types of the uterus to maintain function, however, continues to be a work in progress, given recent discoveries of new participants and targets.

In this review, we highlight emerging evidence documenting the participation of the multi-member Krüppel-like factor (KLF) family of transcription factors and the dynamics of their transcriptional networks and roles in cellular communication in some uterine pathologies. The association of KLFs in ovarian carcinoma is similarly presented because the ovary is the major source of the nuclear receptor ligands estrogen and progesterone

Published by Bioscientifica Ltd 
and because ovarian-related infertility is a major problem in reproductive medicine. Disentangling the various mechanistic points of action of KLFs in these pathologies may aid in the identification of key parameters for optimal reproductive function and contribute to the development of novel treatment strategies and clinical applications to address reproductive disorders.

\section{Krüppel-like factors}

The Specificity-Protein-related KLFs contain 17 members of a family of DNA-binding transcriptional regulators with roles in cellular proliferation, survival, differentiation, pluripotency, and epithelial-to-mesenchymal interactions (Suske et al. 2005). We refer the reader to recent excellent reviews on this family (Tetreault et al. 2013, Knoedler \& Denver 2014, Limame et al. 2014), which now also includes multiple biologically active KLF splice isoforms (Camacho-Vanegas et al. 2013) and the related gene KLF18 that is present in the sequenced genomes of most placental mammals (Pei \& Grishin 2013). KLF proteins are characterized by a conserved DNA-binding domain with three tandem $\mathrm{C}_{2} \mathrm{H}_{2}$-type zinc finger motifs at the carboxy-terminus, which recognizes the GT/GC box or CACCC element sites in promoter $/ 5^{\prime}$ regulatory and enhancer regions (Fig. 1A). In contrast to the carboxytermini, the amino-terminal regions of member proteins are highly variable in length and sequence and contain domains (including acidic transactivation domains, SIN3interacting repressor domains, and CtBP2-interacting repressor domains) that interact with specific co-activators and co-repressors (Kaczynski et al. 2003); the diversity in this region is thought to confer unique functions to each family member. Figure 1B illustrates the sequence homologies between the two highly related family members KLF9 and KLF13, where their respective C-terminal domains display highest similarities for both mouse and human proteins. Based on their phylogenetic

A

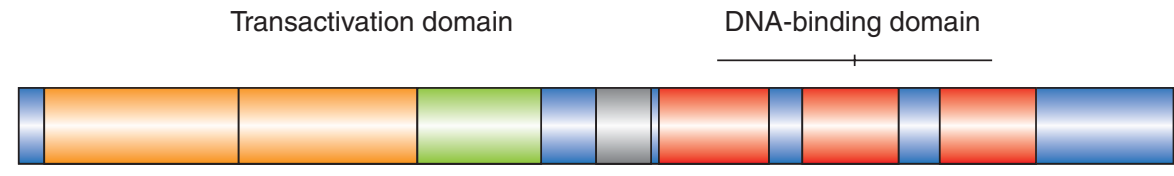

B

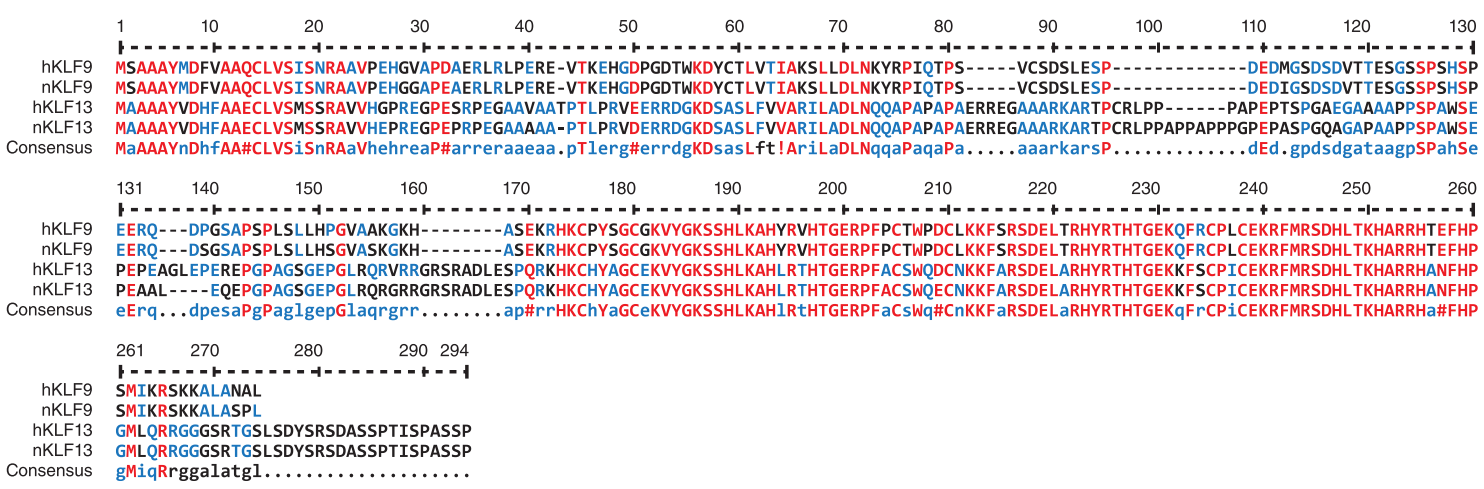

C

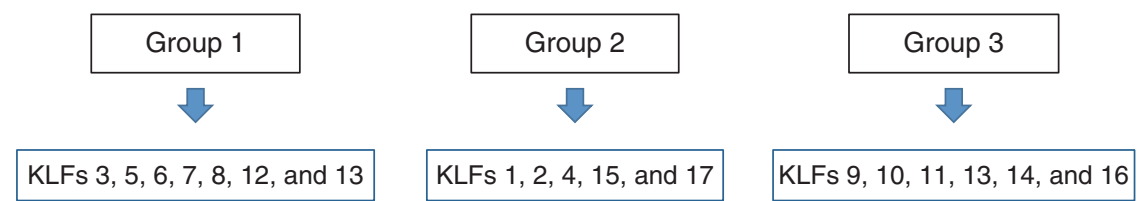

\section{Figure 1}

KLF members and their functional domains. (A) Schematic diagram of the highly variable amino-terminal (transactivation domain) and the highly conserved carboxy-terminal (DNA-binding domain) regions of KLF family proteins. (B) Sequence homologies among human and mouse KLF9 and
(C) 2015 Society for Endocrinology Printed in Great Britain
KLF13 proteins. Invariant (red), conserved (blue), and variable (black) amino acid residues are indicated by single-letter codes. (C) KLFs are assigned to three sub-groups based on their phylogenetic relationships (Limame et al. 2014).

Published by Bioscientifica Ltd 
relationships (Limame et al. 2014), KLF members can be categorized into three sub-groups (Fig. 1C). Interestingly, proteins within the same categories do not typically exhibit similar functions or tissue expression (discussed below), reflecting their distinct regulation, transcriptional activator or repressor roles, and the probable diversity of their interacting proteins in tissue-specific contexts.

\section{KLFs in uterine and ovarian pathologies}

Results from early studies indicated a potential role for KLFs in female reproductive tissues, with our laboratory's initial report on the cloning and expression of KLF9 in the uterus in pregnant pigs (Wang et al. 1997). Results of subsequent investigations using Klf9-null mice indicated that the global loss of KLF9 expression, while not lethal to embryos, caused a subfertility phenotype characterized by reduced numbers of post-implantation embryos (Simmen et al. 2004) and was associated with decreased proliferation and increased apoptosis (glandular and luminal epithelial, stromal) and partial progesterone-resistance (stromal) of endometrial cells during the peri-implantation window (days post-coitum 2.5-3.5) when compared with WT counterparts (Velarde et al. 2005). By using endometrial tissues of WT and Klf9-null mice and KLF9-siRNA targeting of a human endometrial stromal cell line (HESC; Krikun et al. 2004), the mechanistic underpinnings for the aberrant proliferative and apoptotic status with KLF9 loss-of-expression were partly attributed to disruptions in the temporal patterns of expression of the Wnt signaling pathway components $B M P 2, P G R$ (specifically the $P G R-B$ isoform), and insulin-like growth factor-binding protein 1 (IGFBP1) (Pabona et al. 2010). These collective findings provide robust support for the relevance of KLF9 and raise the likelihood of the participation of other KLFs in uterine PGR and Wnt signaling, both of which are major regulators of cellular proliferation, survival, and differentiation.

Uterine and ovarian pathologies that have now been linked to deregulated expression of KLF family members in women and in mouse models are listed in Table 1. It is worth noting that: $i)$ the attenuated expression of multiple KLFs (KLFs 2, 4, 5, 6, 9, and 11) with a few exceptions is relevant to ovarian, endometrial, cervical, and/or myometrial pathologies; ii) the absence of several KLFs in distinct pathologies (e.g. KLF9 and KLF4 in endometrial cancer and endometriosis; KLF9 and KLF11 in endometriosis and leiomyoma) indicates roles for multiple KLFs in maintaining homeostasis in female reproductive tissues; iii) the loss of specific KLFs in various disease states occurs irrespective of their phylogenetic categories (e.g. KLF6 (group 1), KLF2 and KLF4 (group 2) and KLF9 (group 3) in ovarian cancer; KLF4 (group 2) and KLF9 (group 3) in endometrial cancer and endometriosis), implicating distinct KLF-interacting proteins and gene targets as underlying common pathologies; and iv) KLF13 does not appear to be associated with any of the disorders attributed to KLF9, indicative of these proteins' distinct molecular regulation and function. In this regard, KLF13 expression was not altered in endometrial tumors relative to adjacent non-tumor

Table 1 Female reproductive dysfunctions and dysregulated KLF expression in humans $(\mathrm{h})$ and mouse $(\mathrm{m})$ models

\begin{tabular}{|c|c|c|}
\hline Pathology & KLF (species) & $\begin{array}{c}\text { Over }(\uparrow) / \text { under }(\downarrow) \\
\text { expression }\end{array}$ \\
\hline \multirow[t]{3}{*}{ Endometrial cancer } & KLF4 (h) & $\downarrow$ \\
\hline & KLF $9(h)$ & $\downarrow$ \\
\hline & KLF17 (h) & $\uparrow$ \\
\hline \multirow[t]{4}{*}{ Ovarian cancer } & KLF2 (h) & $\downarrow$ \\
\hline & KLF4 (h) & $\downarrow$ \\
\hline & KLF6 (h) & $\downarrow$ \\
\hline & KLF9 (h) & $\downarrow / \uparrow$ \\
\hline \multirow[t]{2}{*}{ Cervical cancer } & KLF4 (h) & $\downarrow$ \\
\hline & KLF5 (h) & $\uparrow$ \\
\hline \multirow[t]{3}{*}{ Endometriosis } & KLF4 (h) & $\downarrow$ \\
\hline & KLF9 $(h, m)$ & $\downarrow$ \\
\hline & $\operatorname{KLF} 11(h, m)$ & $\downarrow$ \\
\hline \multirow{2}{*}{ Leiomyoma } & KLF9 (h) & $\downarrow$ \\
\hline & KLF11 (h) & $\downarrow$ \\
\hline \multirow[t]{2}{*}{ Implantation/pregnancy } & KLF5 (m) & $\downarrow$ \\
\hline & KLF9 (m) & $\downarrow$ \\
\hline Labor dysfunction & KLF9 (h, m) & $\downarrow$ \\
\hline
\end{tabular}

\section{References}

Simmons et al. (2011)

Simmen et al. (2008), Simmons et al. (2011) and Korani et al. (2013) Dong et al. (2014)

Wang et al. (2005)

Yoon \& Roh (2012)

DiFeo et al. $(2006 a, b)$

Huang et al. (2014) and Zhang et al. (2014a)

Yang \& Zheng (2014)

Marrero-Rodríguez et al. (2014)

Adammek et al. (2013)

Lee et al. (2008), Pabona et al. (2012) and Heard et al. (2014)

Daftary et al. (2013)

Rackow \& Taylor (2010)

Yin et al. (2010)

Sun et al. (2012)

Simmen et al. (2004)

Zeng et al. (2008) and Pabona et al. (2015) http://jme.endocrinology-journals.org DOI: $10.1530 / \mathrm{JME}-14-0310$
() 2015 Society for Endocrinology Printed in Great Britain 
Table 2 Human cell lines used to model reproductive dysfunctions associated with dysregulated KLF expression

\begin{tabular}{|c|c|}
\hline Pathology & Cell line \\
\hline \multirow[t]{3}{*}{ Endometrial cancer } & EM/PR \\
\hline & Ishikawa, EEC, and HEC-1A \\
\hline & EEC \\
\hline \multirow[t]{5}{*}{ Ovarian cancer } & OV202 and SKOV3 \\
\hline & SKOV3 and OVCAR3 \\
\hline & SKOV3 \\
\hline & T80 and SKOV3 \\
\hline & SKOV3 and OVCAR3 \\
\hline \multirow[t]{2}{*}{ Endometriosis } & $12 Z$ \\
\hline & HESC \\
\hline \multirow[t]{2}{*}{ Implantation defects } & HESC \\
\hline & HESC \\
\hline Labor dysfunction & HutSMC \\
\hline
\end{tabular}

\begin{tabular}{l} 
KLF \\
\hline KLF4 \\
KLF9 \\
KLF17 \\
KLF2 \\
KLF4 \\
KLF5 \\
KLF8 \\
KLF9 \\
KLF4 \\
KLF9 \\
KLF9 \\
KLF12 \\
KLF9
\end{tabular}

\begin{tabular}{l} 
References \\
\hline Shimizu et al. (2010) \\
Simmen et al. (2008) and Simmons et al. (2011) \\
Dong et al. (2014) \\
Wang et al. (2005) \\
Yoon \& Roh (2012) and Chen et al. (2014) \\
Dong et al. (2013) \\
Lu et al. (2012) \\
Zhang et al. (2014a) \\
Adammek et al. (2013) \\
Pabona et al. (2012) \\
Pabona et al. (2010) \\
Shen et al. (2013) \\
Pabona et al. (2015)
\end{tabular}

tissue in women with endometrial cancer (Simmons et al. 2011). Moreover, Klf13-null mice did not exhibit the subfertility and prolonged labor phenotypes found for Klf9-null mutants (Heard et al. 2012).

Given the paucity of currently available mouse models and limited access to human tissues for studying KLF function in the uterus and ovary, human cell lines that model reproductive disease states have been used to dissect mechanisms of action of particular KLFs. These cell lines are summarized in Table 2. The human Ishikawa, endometrial endocarcinoma (EEC), and human endometrial carcinoma-1A (HEC-1A) cell lines have been investigated as models for endometrial carcinoma. The ovarian cancer cell lines OV202, SKOV3, OVCAR3, and, to a limited extent, T80 have been employed to model ovarian cancer. Furthermore, the HESC line, generated by overexpression of human telomerase and shown to be progesterone-responsive (Krikun et al. 2004), is commonly used as a paradigm for HESCs during early pregnancy, due to their ability to decidualize in vitro after treatments with a cocktail of cAMP, estrogen, and progesterone, and can be evaluated for poor decidual response upon targeting specific KLF siRNA (Pabona et al. 2010, Shen et al. 2013). To mimic the labor dysfunction observed with Klf9-null mice (Zeng et al. 2008), the response of a recently generated human uterine smooth muscle cell line HutSMC was tested in estrogen+progesterone-treated cells without or with KLF9 siRNAs (Pabona et al. 2015). While such studies have resulted in the identification of common and distinct pathways for KLFs (Fig. 2), there are acknowledged limitations of the use of cell lines with regard to extending relevance to the whole organism, providing impetus for generation of new and reproductivesystem-targeted mouse models to further elucidate the dynamics of KLF actions in vivo.

\section{KLFs and targeted signaling pathways in uterine pathologies}

As KLFs are known to regulate cell proliferation, survival, and differentiation, it is quite expected that their reduced expression in many uterine diseases (Table 1) will be associated with perturbations in signaling pathways for PGR and ESR, Wnt, Notch, Hedgehog (Hh), immune activation, and epithelial-to-mesenchymal transitions, all of which are requisite for maintenance of uterine integrity and function (Fig. 2). Whether cross-talk between these pathways is mediated by actions of KLFs is not completely understood, albeit limited reports of results supporting this possibility for PGR and the Notch/Hh signaling pathways. In one study, ectopic lesions formed from Klf9-null endometrial tissues in a mouse model displayed activated Notch and Hh signaling and conversely reduced PGR expression (Heard et al. 2014). Moreover, eutopic endometria of women with endometriosis, a disease state characterized by loss of progesterone-sensitivity, display reduced KLF9 (Pabona et al. 2012) and enhanced Notch 3 (Tamaresis et al. 2014) expression. Reduced progesteronesensitivity with the loss of KLF9 is in part due to KLF9's role as a PGR-interacting protein (Zhang et al. 2002, 2003) and its promotion of estrogen-dependent ESR1 downregulation (Velarde et al. 2007). As regards progesterone/ PGR-Notch-Hh signaling pathways, their opposing and complementary associations in endometrial cells have been demonstrated. For example, the transcript levels of the Notch ligand, Delta-like 4 are reduced by medroxyprogesterone acetate in primary cultures of human endometrial glandular and stromal cells (Mazella et al. 2008). Moreover, the Hh ligand Indian $\mathrm{Hh}$ is a negatively regulated downstream target of progesterone/PGR (Simon et al. 2009). On the other hand, Notch 1 has been shown

Published by Bioscientifica Ltd 


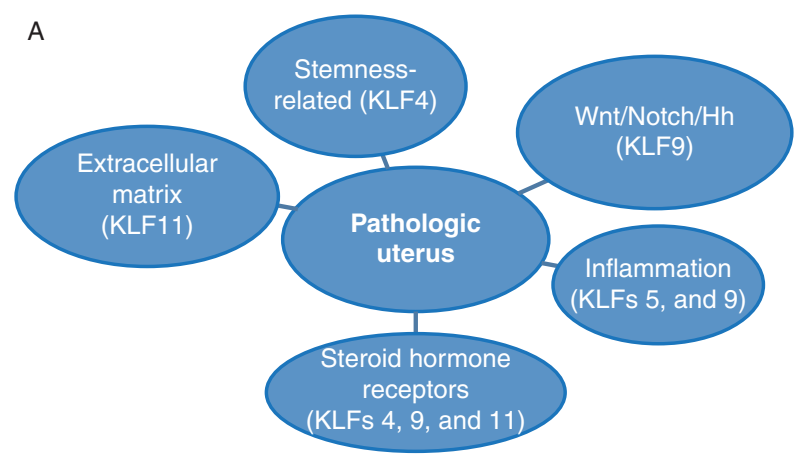

B

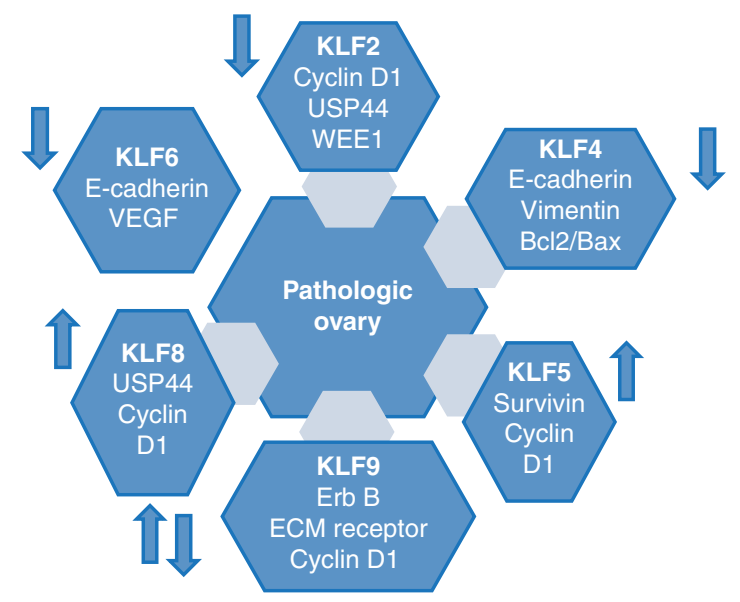

Figure 2

Signaling pathways and gene targets associated with dysregulated expression of KLF family members in the pathologic uterus (A) and ovary (B). Arrows in B ( $\uparrow$ and $\downarrow)$ signify upregulated and downregulated expression of each KLF in ovarian carcinoma.

to mediate progesterone-dependent uterine stromal cell differentiation in primates and mice (Afshar et al. $2012 a, b$ ). In addition, progesterone increased the levels of transcriptionally active Notch 1 intracellular domain, which can form a functional complex with PGR (Afshar et al. 2012a). The potential complexity of the regulatory networks involving PGR and Notch/Hh signaling indicates that no single mechanism may fully account for each KLF acting through these pathways.

A core KLF circuitry comprising KLF2, KLF4, and KLF5 has been recently implicated in the regulation of the selfrenewal of embryonic stem cells involving key pluripotency genes (Jiang et al. 2008). By regulating adult stem cell signaling pathways (e.g. Wnt and Notch), KLFs may similarly control the regenerative capacity of endometrial and myometrial stem/progenitor cells. In this regard, endometriosis (Sasson \& Taylor 2008) and leiomyoma (Ono et al. 2014) are increasingly considered to be a consequence of deregulated stem cell expansion. Indeed, endometrial epithelial stem/progenitor cells have been characterized from eutopic endometrium of women with endometriosis (Li et al. 2014), ovarian endometriotic cysts (Chan et al. 2011), endometrial carcinoma tissues (Hubbard et al. 2009), and uterine leiomyoma (Ono et al. 2012). KLF4 is a well-acknowledged regulator of stem cell biology and is the most highly implicated KLF in both cancer and normal stem cells (Tetreault et al. 2013). KLF4 also mediates the action of PGR in human endometrial epithelial cells (Shimizu et al. 2010), albeit unlike KLF9, KLF4 has not been shown to interact with PGR. However, KLF4 expression (Adammek et al. 2013), similar to that of KLF9 (Pabona et al. 2012), is reduced in the eutopic endometria of women with endometriosis (relative to those of women without the disease) and in endometrial tumors relative to adjacent normal tissues (Simmons et al. 2011). Results from recent studies have indicated that the loss of KLF9 expression promotes neurosphere formation (an in vitro measure of 'stemness') in neuroblastoma cells (Ying et al. 2011); this involved activation of Wnt signaling and KLF9 transcriptional repression of integrin$\alpha 6$ expression (Ying et al. 2014). While the results of the studies described above provide causative support for loss of KLF9 expression in the aberrant promotion of 'stemness', direct evidence for the involvement of KLF9 and KLF4 in uterine diseases remains to be fully characterized.

Several KLFs have been directly linked to the regulation of inflammatory signaling, defects of which may contribute to uterine pathology. In particular, uterine-specific Klf5-null mice are infertile due to aberrant expression of the prostaglandin synthesis gene Ptgs2, resulting in the enhanced expression of COX2 (Sun et al. 2012). Similarly, KLF11, the attenuated expression of which is linked to uterine leiomyoma, has been reported to inhibit prostaglandin $\mathrm{E}_{2}$ synthesis by transcriptionally silencing the promoter of the gene encoding phospholipase $A_{2 \alpha}$, the key enzyme for prostaglandin biosynthesis (Buttar et al. 2010). Furthermore, KLF4 was shown to stimulate monocyte differentiation in the human acute myeloid leukemia cell line HL60 (Alder et al. 2008) and to enhance macrophage activation in the macrophage cell line J774a (Feinberg et al. 2005), indicating a role in immune modulation that is critical for uterine function. In women, prolonged pregnancy is associated with reduced expression of KLF9 and with aberrant downregulation and upregulation of several pro-inflammatory and anti-inflammatory genes respectively (Pabona et al. 2015). Given that a number of inflammation-associated genes are direct PGR targets (e.g. IL11 and CXCL1;

Published by Bioscientifica Ltd. 
Cordeaux et al. 2010, Kavandi et al. 2012), results indicate that the deregulated expression of numerous inflammatory mediators may be a direct outcome of aberrant PGR signaling involving KLFs. In a recent study, Rogatsky and colleagues (Chinenov et al. 2014) have described the functional cooperation between the glucocorticoid receptor and KLF2 and KLF9 in macrophages during inflammation. As the glucocorticoid receptor can mediate the effects of progestin on uterine inflammatory response (Guo et al. 2012, Lei et al. 2012), The interaction of KLF with progesterone-dependent transcriptional circuitry is a possible node by which KLFs may exert their control over inflammatory events in the uterus.

Additional pathways that have been linked to KLFs and that may underlie a number of uterine pathologies when these KLFs are aberrantly expressed include: the promotion by KLF17 of epithelial-to-mesenchymal transitions through induction of TWIST1 in endometrial cancer (Dong et al. 2014); the coactivation by KLF6 of NFKB signaling via its induction of the cytokines tumor necrosis factor $\alpha$ and interleukin 6 (Zhang et al. 2014b) in the pathogenesis of endometriosis; KLF5-mediated activation of the JAK-STAT signaling pathway (Tetreault et al. 2012), the latter being a key mediator of leukemia inhibitory factor that controls embryo implantation and hence successful pregnancy (Rosario et al. 2014); and KLF14- (de Assuncao et al. 2014) and KLF11- (Zheng et al. 2014) mediated activation of lipid and metabolic signaling, respectively, processes that when dysregulated can lead to abnormal metabolism and increased risk of endometrial cancer.

Reproductive aging is a natural biological process and does not fall into the category of a uterine pathology (Nelson et al. 2013); however, societal demands based on a woman's choice to time her pregnancy have raised the need to further understand age-related co-morbidities of the uterus and ovary, which can be modified for successful pregnancy outcome. To begin to evaluate a potential role for KLFs in this process, we measured the transcript levels of several KLF family members in uteri of young ( 8 months; $n=7$ ) and old (27 months; $n=7$ ) C57BL/ 6 mice by quantitative RT-PCR. Of the nine KLFs analyzed, only the mRNAs for Klf9 and Klf4 displayed significant differences as a function of age; the levels of Klf8, Klf13, and Klf15 transcripts only showed tendencies towards differences (Fig. 3). Using a stem-cellfocused PCR array, we also searched for potential differentially regulated genes associated with the aging uterus. The transcripts of a number of cell-cycle regulators, cytokines, and self-renewal markers were distinctly regulated during aging (Table 3). While it is premature to establish a correlation between aging and the KLFs based on the results of this pilot

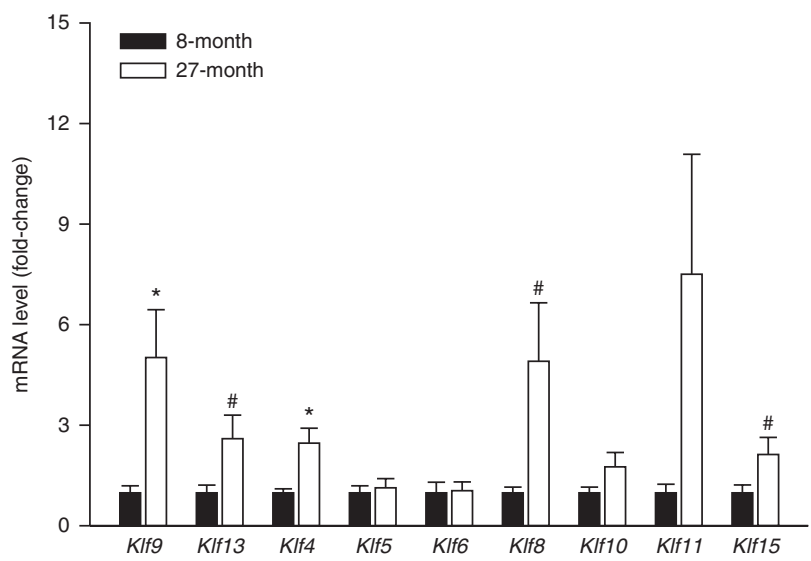

Figure 3

Expression of selected KLFs in uteri of young and aging mice. Transcript levels of various KLFs were quantified in uteri of 8- and 27-month-old C57BL/6 mice by quantitative RT-PCR. Data (mean \pm s.E.M.) are expressed as fold-change and were obtained from $n=7$ individual mice/age group. Transcript levels were normalized to corresponding levels of 18S RNA, and then to controls (8-month-old uteri) and were calibrated to a standard curve using pooled cDNA stocks. *Significant at $P<0.05$, by $t$-test; \#, tending to significance with $0.05<P<0.10$.

study, the well-recognized reductions in the reservoir of uterine stem cells with aging together with the suggested roles of KLFs in stem cell self-renewal provide a reasonable basis for utilizing the aging uterus as a unique model to further evaluate a potential link between stem cell biology and KLFs.

\section{KLFs and targeted signaling pathways in ovarian pathologies}

It is notable that for those mice with global null-mutations of specific KLFs (e.g. KLF9, KLF11, and KLF13) and surviving through adulthood, an ovarian phenotype characterized by dysfunctions in steroid hormone synthesis is not manifested throughout the reproductive years (Simmen et al. 2004, Zeng et al. 2008, Heard et al. 2012, Daftary et al. 2013). This finding is not congruent with the demonstrated regulation of transcript levels of several key steroidogenic genes (LDLR, STAR, and CYP11A) by KLF13 in ovarian granulosa cells (Natesampillai et al. 2008). Interestingly, the pathological ovary (i.e. ovarian carcinoma) is characterized by reduced (KLF2, KLF4, and $K L F 6)$ and enhanced (KLF5 and KLF8) expression of several KLFs; contradictory results have been reported for KLF9 (Fig. 2B). Analyses of currently identified target genes associated with dysregulation of distinct KLF expression in ovarian cancer cells revealed perturbations in those related to proliferation and differentiation (cyclin D1); apoptosis (Bcl2, Bax, and survivin); epithelial-to-mesenchymal

Published by Bioscientifica Ltd. 
Table 3 Differentially expressed genes in the aging uterus

\begin{tabular}{|c|c|}
\hline Genes $^{a}$ & Fold-change $^{b}$ \\
\hline \multicolumn{2}{|c|}{ Cell cycle regulators/Wnt signaling } \\
\hline$A p c$ & -2.10 \\
\hline Axin1 & -2.75 \\
\hline Ccna2 & -8.40 \\
\hline Ccnd1 & -7.36 \\
\hline Ccne1 & -4.99 \\
\hline Myc & -2.48 \\
\hline \multicolumn{2}{|c|}{ Cytokines/growth factors } \\
\hline$B m p 1$ & -6.06 \\
\hline $\mathrm{CxCl} 12$ & -4.56 \\
\hline Fgf1 & 2.17 \\
\hline Fgf2 & -2.64 \\
\hline lgf1 & -3.81 \\
\hline \multicolumn{2}{|c|}{ Self-renewal markers } \\
\hline $\mathrm{Cd} 44$ & -9.19 \\
\hline$M s \times 1$ & -7.26 \\
\hline $\operatorname{Jag} 1$ & -1.64 \\
\hline Hspa9 & -2.58 \\
\hline Myst1 & -3.48 \\
\hline
\end{tabular}

aldentified using stem cell signaling qPCR array.

${ }^{\mathrm{b}}$ Aging versus young uterus: $(-)$ down-regulation.

interactions (E-cadherin, vimentin, and extracellular matrix receptor); stem cell differentiation (USP44, ErbB); and angiogenesis (VEGF). These findings raise important questions regarding how KLFs alone or together may integrate the physiological processes in the ovary and whether pathways defined for uterine pathologies in which multiple KLFs (e.g. KLF4 and KLF5) are similarly dysregulated may be relevant to ovarian diseases.

\section{KLF networks: a case for and against functional redundancy}

As KLF expression is ubiquitous, yet known reproductive system pathologies appear to involve selected subsets of KLFs (Table 1), functional redundancies and compensatory regulation among KLFs must exist to ensure robust physiological responses to cellular perturbations for maintaining homeostasis. Results of recent elegant studies have been used to demonstrate this concept for KLF3 and KLF8 in a nonreproductive (i.e. erythroid) system (Eaton et al. 2008, Funnell et al. 2013). The lack of distinct uterine phenotypes in mouse knockout models for several genes encoding KLFs supports this concept for the reproductive tract. A prime example involves the highly related members KLF9 and KLF13. Although the ability to draw a definitive conclusion is limited by the lack of functional studies of mice deficient for both KLFs, support for a KLF9-KLF13 genetic interaction comes from findings that Klf9-null mouse uteri at periimplantation displayed increased Klf13 expression, which was confirmed using siKLF9-targeted HESCs (Pabona et al. 2010). Moreover, Klf13-null mice are reproductively normal, perhaps due to the accompanying increase in nuclear KLF9 protein levels shown for Klf13-null endometrial cells (Heard et al. 2012). Thus, the absence of an association between KLF13 and any reproductive dysfunctions reported to date (Table 1) may be a consequence of the placement of KLF9 at a higher level of the functional hierarchy relative to KLF13. In this scenario, potential transcriptional dysregulation that may occur with loss of KLF13 expression is abrogated by the compensatory actions of KLF9.

The co-reduction in KLF9 and KLF4 expression noted in endometrial cancer and in endometriosis and those of KLF9 and KLF11 in endometriosis and in leiomyoma (Table 1) on the other hand supports the concept of distinct programs of gene expression being controlled by these KLFs. Alternatively, this may indicate that there is an obligatory pathway that is mediated by two KLFs occurring through a linear mechanism. There is evidence for the latter possibility, at least for KLF9 and KLF4. Knockdown of KLF9 with siRNA in the HEC Ishikawa cell line reduced the levels of KLF4 transcripts (Simmons et al. 2011) and conversely, overexpression of KLF9 in HEC-1A cells induced the expression of KLF4 (Simmen et al. 2008); these observations are in accordance with the hypothesis (albeit yet to be proven) that KLF4 serves as a downstream target of KLF9 either directly or indirectly. Parallel transcriptome and ChiP-Seq analyses of uterine cells subjected to siKLF9 and siKLF4 targeting, alone and in combination, will be required to identify unique and shared networks regulated by the two KLFs and could provide an insight regarding whether KLF4 is an early target of KLF9. Importantly, such studies may allow the identification of an obligate response (gene target, signaling pathway) mediated by both KLFs. With regards to KLF9 and KLF11, there are limited data to support or refute redundant functions; however, based on their distinct reproductive phenotypes upon targeted gene inactivation (Klf11-null mice breed normally and are fertile in contrast to Klf9-null mice that are subfertile; Simmen et al. 2004, Song et al. 2005) and the distinct mechanisms by which they mediate PGR transactivity (Zhang et al. 2003, Yin et al. 2010), they are likely to differentially mediate PGR-driven transcriptional events in uterine cells.

The opposing actions of KLF4 and KLF15 in uterine epithelial cells constitute additional support for nonredundant functions of KLF family members. In these cells, KLF4 and KLF15 are inversely expressed, and are found to discretely regulate initiation of DNA synthesis by virtue of their distinct responses to estrogen- and

Published by Bioscientifica Ltd 
progesterone-treatments (Ray \& Pollard 2012). By inhibiting estrogen-enhanced transcription of the DNA synthesis initiator protein minichromosome maintenance 2, KLF15 functions as a downstream mediator of progesteroneinhibition of the cell cycle. The factors that direct the inverse expression of KLF4 and KLF15 and their opposing responses to steroid hormones in the uterine epithelium have yet to be determined. Clearly, the biology underlying optimal uterine function involving KLF regulatory networks is wide-open for further investigations.

\section{Regulation of KLF expression}

The factors that contribute to the aberrant expression and activity of KLFs in reproductive tract pathology have not been well-characterized, in contrast to other systems. In embryonic stem cells, induction of KLF2 by OCT4 and of KLF4 by LIF has been demonstrated, providing further evidence supporting these KLFs' function in stem cell renewal (Hall et al. 2009). KLF4 expression was suppressed by the transcription factor FOXO in B-lymphocytes (Yusuf et al. 2008) and by an inhibitor of Notch signaling in the mouse gastrointestinal tract (Zheng et al. 2009) and, conversely, was induced by Notch 1 intracellular domain in ocular surface epithelia (Zhang et al. 2013). KLF6 expression was stimulated by IGF1 in human colon cancer cell lines (Bentov et al. 2008), and the binding of carbohydrate-response-element-binding protein, a glucoseactivated transcription factor, induced KLF10 promoter activity and expression in rat hepatocytes (Iizuka et al. 2011). The identity of factors that regulate KLF expression in uterine cells is currently limited to that of KLF9 in HESCs; in these cells, BMP2 inhibited KLF9 expression indirectly through KLF13 (Pabona et al. 2010) while estrogen and progesterone had no influence on its expression (Pabona et al. 2012). In ovarian granulosa cells, IGF1 and luteinizing hormone $(L H)$ were reported to increase the expression of KLF13 (Natesampillai et al. 2008). Comprehensive analyses of cellular components responsible for maintaining KLF expression will be required in order to understand and ultimately manipulate KLF regulatory circuits for optimal reproductive function.

\section{The next steps: a perspective}

In the last decade, multiple molecular pathways mediated by KLFs have been elucidated in uterine and ovarian cells and tissues. Nevertheless, direct evidence linking KLF effects to health outcomes and disease states remains elusive. How may we address this gap in knowledge? In most cases, the difficulty lies in the absence of mouse models that recapitulate the human disease and in the possible biological redundancies among subsets of KLFs that may prevent abnormal responses being observed when one KLF is absent. Thus, using relevant cell lines in vitro by siRNA targeting and by characterizing uterine (or ovarian)-targeted KLF-combination knockouts in vivo, it is imperative to establish which subsets of KLFs compensate for each other. Many of the mouse mutants for KLFs have modest or no reproductive phenotypes when they survive to adulthood (e.g. Klf9-, Klf11-, and Klf13-null mice). For other KLFs, homozygous disruptions result in early embryo (for Klf4, Klf5, and Klf6), in utero (for Klf2), and neonatal (for Klf7) lethality (Wani et al. 1999, Laub et al. 2006, Matsumoto et al. 2006, Ema et al. 2008). Therefore, for these KLFs, conditional mutations using uterine epithelial-, stromal-, and myometrial-tissuespecific promoters driving the Cre-recombinase may serve as a powerful strategy for studying gene function in each cell type. Such studies are anticipated to be labor-intensive and complex, given that the uterus has multiple cellular compartments and that several KLFs exhibit preferential cellular expression (e.g. KLF9 in endometrial stroma and myometrium; Simmen et al. 2004). Indeed, the complexity of 'teasing out' the details of KLF signaling in each compartment is best illustrated when one considers that for the progesterone/PGR signaling pathway alone, distinct KLFs are involved either as regulators or integrators of progesterone/PGR transactivity, albeit not necessarily in the same physiological contexts (Fig. 4). To date, proliferative, survival, and pro-/anti-inflammatory molecular signatures elicited by each KLF family member have not been defined when null-mutated in specific uterine compartments. The power of increasingly sophisticated approaches such as ChiP-Seq, various 'omics' technologies, and precise genome editing methodologies using engineered nucleases offered by the clustered regularly interspaced short palindromic repeats (CRISPR) with CRISPR-associated (Cas) proteins should be harnessed to address this question.

So why study KLFs in the face of their seeming complexity? In this review, the present data indicating i) their association with many reproductive disorders, whose etiologies are not well-understood; ii) their control of a plethora of signaling pathways; and iii) the considerable diversity of their target genes due to their ability to act as transcriptional activators or repressors, collectively indicate their prominent roles as integrators of uterine (and ovarian) biology. Perhaps an exciting direction for KLF research is one that focuses on their transcriptional roles in uterine and ovarian stem cell biology. It is well-known that the endometrium displays dramatic regenerative properties,

Published by Bioscientifica Ltd. 


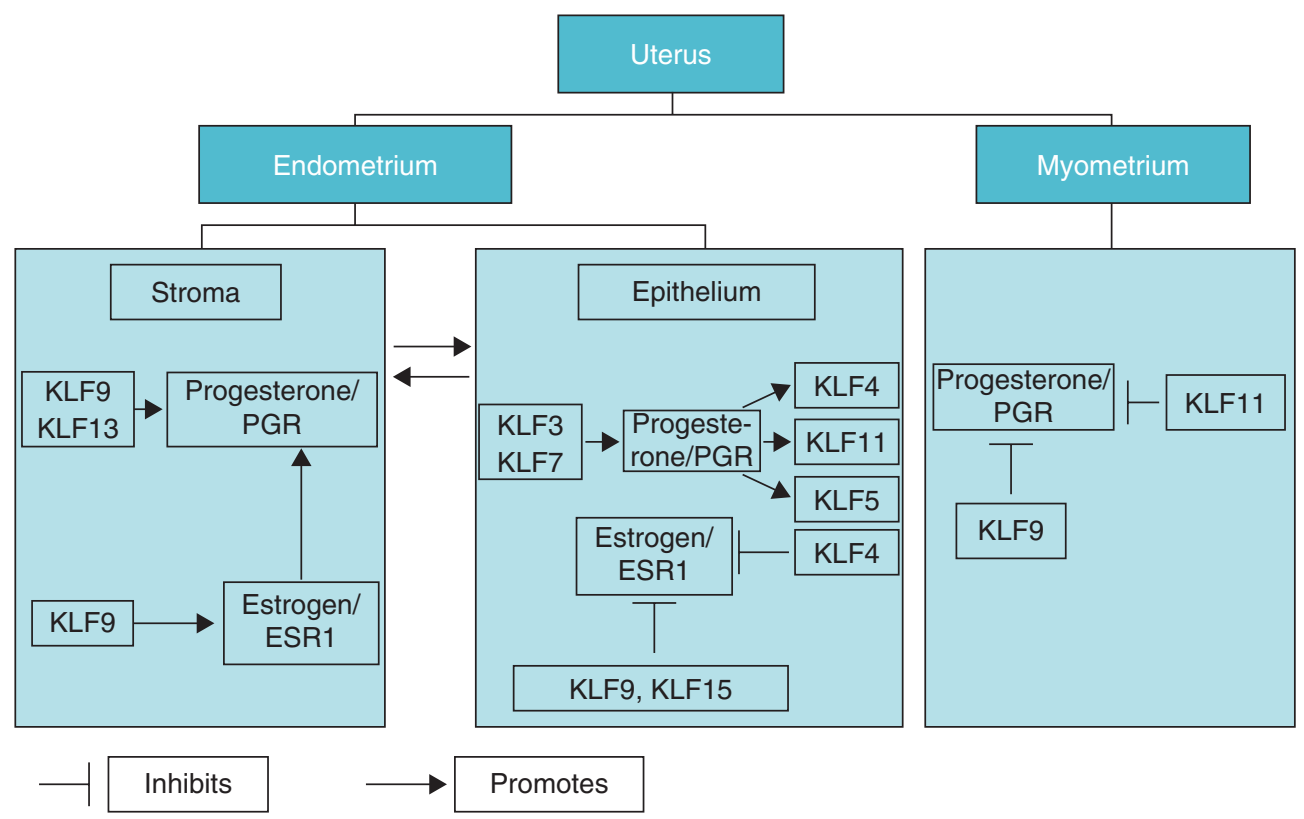

\section{Figure 4}

Complex and redundant control of PGR and ESR1 signaling by KLFs in distinct uterine compartments. Promotion or inhibition of PGR and ESR1 activity may occur by direct or indirect mechanisms. Arrows originating from progesterone/PGR (in epithelium) indicate KLFs acting as integrators

estimated to occur approximately 400-times during a woman's reproductive years; these have been linked to the presence of adult stem cells displaying key properties of mesenchymal stem cells (Figueira et al. 2011, Spitzer et al. 2012). In a recent study, Taylor and colleagues (Sakr et al. 2014) demonstrated that mesenchymal stem cells are recruited to endometriosis lesions and that reduction of this recruitment can diminish lesion incidence. Similarly, a small population of cells (approximately 1\% of tumor cells) showing stem-progenitor properties was found to be essential for estrogen + progesterone-dependent growth of uterine leiomyomas (Ono et al. 2012). Interestingly, the growth of this cell population involves ESR/PGR-Wnt signaling pathway crosstalk via estrogen + progesteroneinduced $\beta$-catenin translocation, leading to Axin 2 promoter activation (Ono et al. 2013). As loss of KLF11 expression is associated with increased PGR signaling and proliferation of leiomyoma cells (Yin et al. 2010), it is tempting to consider that inhibition of the aberrant expansion of myometrial smooth muscle stem cells by KLF11 may avert tumor initiation and leiomyoma.

How will understanding the biology of KLFs lead to novel and more effective therapies for female reproductive disorders? To date, treatment options for most uterine disorders involve aromatase inhibitors and progestins; however, prolonged treatment with these agents can result in drug of progesterone/PGR signaling. Bi-directional arrows between stroma and epithelium signify the dynamic communication between the two endometrial compartments.

resistance, with disease recurring often after cessation of treatment. If current results indicating that KLFs integrate progesterone/PGR and estrogen/ESR crosstalk with NotchWnt pathways to control aberrant stem/progenitor cell proliferation are verified, it may be possible to develop nonsteroidal treatments that target specific 'stemness' factors such as the Notch ligand JAGGED1, which promote the survival of this subpopulation and therefore progression/ recurrence of uterine pathologies. Thus, targeting Notch signaling using $\gamma$-secretase inhibitors that inhibit the intracellular localization of the transcriptional mediator Notch intracellular domain may offer a viable therapeutic strategy. A proof-of-concept for the latter has been recently performed for uterine serous carcinoma in a human xenograft model in mice (Groeneweg et al. 2014). In a recent report, small-molecule inhibitors of the expression of the colorectal cancer oncogene KLF5 has been identified by high-throughput screening of compound libraries (Bialkowska et al. 2011). The isolated compounds, screened using a rat intestinal cell line stably expressing a luciferase reporter driven by the human KLF5 promoter, reduced endogenous KLF5 protein levels and decreased the viability of a number of colorectal cancer cell lines. A similar strategy may also be employed to elude reproductive pathologies, although compounds promoting, rather than inhibiting, KLF expression will need to be identified because uterine pathologies are mostly

Published by Bioscientifica Ltd. 
associated with reduced KLF expression (Table 1). Such approaches could yield novel research outcomes valuable for translation into clinical applications.

Finally, it is worth noting that the major male reproductive disease, namely prostate cancer, is also highly associated with dysfunctions in numerous KLFs including KLF4 (Wang et al. 2010), KLF5 (Frigo et al. 2009), KLF6 (Narla et al. 2001), KLF8 (He et al. 2013), and KLF9 (Shen et al. 2014). Importantly, a number of signaling pathways reported for KLF (dys)regulation of prostate epithelial cell proliferation, differentiation, and survival overlap with those elucidated for KLF-mediated uterine function. In particular, KLFs have been reported to participate in androgen-receptor-dependent signaling (Liu et al. 2012, He et al. 2013), the male counterpart of PGR/ESR signaling in females, in regulation of $\mathrm{Hh}$ pathway components (Leow et al. 2009), and in stem cell signaling involving the Notch pathway (Oktem et al. 2014). However, no KLFs have been demonstrated so far to be indispensable for spermatogenesis.

\section{Conclusion}

The growing evidence for the functional and correlative association of KLFs in various female (and male) reproductive pathologies underscores the importance of extending and expanding current knowledge of this multi-faceted transcription factor family in reproductive health. New possibilities for targeting KLFs may soon be available from reproductive-system-wide analysis of KLF signaling. Treatment of other reproductive pathologies, including preeclampsia, fallopian tube cancers, and recurrent pregnancy loss, as well as male infertility, may similarly be benefited by an understanding of KLF biology.

\section{Declaration of interest}

The authors declare that there is no conflict of interest that could be perceived as prejudicing the impartiality of this review.

\section{Funding}

Work at our laboratory described in this review was supported in part by the United States National Institutes of Health Grants HD21961 and CA136493.

\section{Acknowledgements}

The authors thank Dr Frank A Simmen for his critical review of this manuscript.

\section{References}

Adammek M, Greve B, Kässens N, Schneider C, Brüggemann K, Schüring AN, Starzinski-Powitz A, Kiesel L \& Götte M 2013 MicroRNA miR-145 inhibits proliferation, invasiveness, and stem cell phenotype of an in vitro endometriosis model by targeting multiple cytoskeletal elements and pluripotency factors. Fertility and Sterility 99 1346-1355. (doi:10.1016/j.fertnstert.2012.11.055)

Afshar Y, Miele L \& Fazleabas AT 2012a Notch1 is regulated by chorionic gonadotropin and progesterone in endometrial stromal cells and modulates decidualization in primates. Endocrinology 153 2884-2896. (doi:10.1210/en.2011-2122)

Afshar Y, Jeong JW, Roqueiro D, DeMayo F, Lydon J, Radtke F, Radnor R, Miele L \& Fazleabas A 2012b Notch1 mediates uterine stromal differentiation and is critical for complete decidualization in the mouse. FASEB Journal 26 282-294. (doi:10.1096/fj.11-184663)

Alder JK, Georgantas RW III, Hildreth RL, Kaplan IM, Morisot S, Yu X, McDevitt M \& Civin CI 2008 Krüppel-like factor 4 is essential for inflammatory monocyte differentiation in vivo. Journal of Immunology 180 5645-5652. (doi:10.4049/jimmunol.180.8.5645)

de Assuncao TM, Lomberk G, Cao S, Yaqoob U, Mathison A, Simonetto DA Huebert RC, Urrutia RA \& Shah VH 2014 New role for Krüppel-like factor 14 as a transcriptional activator involved in the generation of signaling lipids. Journal of Biological Chemistry 289 15798-15809. (doi:10.1074/jbc.M113.544346)

Bentov I, Narla G, Schayek H, Akita K, Plymate SR, LeRoith D, Friedman SL \& Werner H 2008 Insulin-like growth factor-I regulates Krüppel-like factor-6 gene expression in a p53-dependent manner. Endocrinology 149 1890-1897. (doi:10.1210/en.2007-0844)

Bialkowska AB, Crisp M, Bannister T, He Y, Chowdhury S, Schürer S, Chase P Spicer T, Madoux F, Tian C et al. 2011 Identification of small-molecule inhibitors of the colorectal cancer oncogene Krüppel-like factor 5 expression by ultrahigh-throughput screening. Molecular Cancer Therapeutics 10 2043-2051. (doi:10.1158/1535-7163.MCT-11-0550)

Buttar NS, DeMars CJ, Lomberk G, Rizvi S, Bonilla-Velez J, Achra S, Rashtak S, Wang KK, Fernandez-Zapico ME \& Urrutia R 2010 Distinct role of Krüppel-like factor 11 in the regulation of prostaglandin $\mathrm{E}_{2}$ biosynthesis. Journal of Biological Chemistry 285 11433-11444. (doi:10.1074/ jbc.M109.077065)

Camacho-Vanegas O, Till J, Miranda-Lorenzo I, Ozturk B, Camacho SC \& Martignetti JA 2013 Shaking the family tree: identification of novel and biologically active alternatively spliced isoforms across the KLF family of transcription factors. FASEB Journal 27 432-436. (doi:10.1096/fj.12220319)

Chan RW, Ng EH \& Yeung WS 2011 Identification of cells with colony-forming activity, self-renewal capacity, and multipotency in ovarian endometriosis. American Journal of Pathology 178 2832-2844. (doi:10.1016/j.ajpath.2011.02.025)

Chen Z, Wang Y, Liu W, Zhao G, Lee S, Balogh A, Zou Y, Guo Y, Zhang Z, $\mathrm{Gu}$ W et al. 2014 Doxycycline inducible Krüppel-like factor 4 lentiviral vector mediates mesenchymal to epithelial transition in ovarian cancer cells. PLOS ONE 9 e105331. (doi:10.1371/journal.pone.0105331)

Chinenov Y, Coppo M, Gupte R, Sacta MA \& Rogatsky I 2014 Glucocorticoid receptor coordinates transcription factor-dominated regulatory network in macrophages. BMC Genomics 15656. (doi:10.1186/1471-2164-15-656)

Cordeaux Y, Tattersall M, Charnock-Jones DS \& Smith GC 2010 Effects of medroxyprogesterone acetate on gene expression in myometrial explants from pregnant women. Journal of Clinical Endocrinology and Metabolism 95 437-447. (doi:10.1210/jc.2010-1541)

Daftary GS, Zheng Y, Tabbaa ZM, Schoolmeester JK, Gada RP, Grzenda AL, Mathison AJ, Keeney GL, Lomberk GA \& Urrutia R 2013 A novel role of the $\mathrm{Sp} / \mathrm{KLF}$ transcription factor KLF11 in arresting progression of endometriosis. PLOS ONE 8 e60165. (doi:10.1371/journal.pone. 0060165)

Published by Bioscientifica Ltd. 
Dasgupta S \& O'Malley BW 2014 Transcriptional coregulators: emerging roles of SRC family of coactivators in disease pathology. Journal of Molecular Endocrinology 53 R47-R59. (doi:10.1530/JME-14-0080)

DiFeo A, Narla G, Camacho-Vanegas O, Nishio H, Rose SL, Buller RE, Friedman SL, Walsh MJ \& Martignetti JA $2006 a$ E-cadherin is a novel transcriptional target of the KLF6 tumor suppressor. Oncogene 25 6026-6031. (doi:10.1038/sj.onc.1209611)

DiFeo A, Narla G, Hirshfeld J, Camacho-Vanegas O, Narla J, Rose SL, Kalir T, Yao S, Levine A, Birrer MJ et al. 2006b Roles of KLF6 and KLF6-SV1 in ovarian cancer progression and intraperitoneal dissemination. Clinical Cancer Research 12 3730-3739. (doi:10.1158/1078-0432.CCR-06-0054)

Dong Z, Yang L \& Lai D 2013 KLF5 strengthens drug resistance of ovarian cancer stem-like cells by regulating survivin expression. Cell Proliferation 46 425-435. (doi:10.1111/cpr.12043)

Dong P, Kaneuchi M, Xiong Y, Cao L, Cai M, Liu X, Guo SW, Ju J, Jia N, Konno Y et al. 2014 Identification of KLF17 as a novel epithelial to mesenchymal transition inducer via direct activation of TWIST1 in endometrioid endometrial cancer. Carcinogenesis 35 760-768. (doi:10.1093/carcin/bgt369)

Eaton SA, Funnell AP, Sue N, Nicholas H, Pearson RC \& Crossley M 2008 A network of Krüppel-like factors (Klfs). Klf8 is repressed by Klf3 and activated by Klf1 in vivo. Journal of Biological Chemistry $\mathbf{2 8 3}$ 26937-26947. (doi:10.1074/jbc.M804831200)

Ema M, Mori D, Niwa H, Hasegawa Y, Yamanaka Y, Hitoshi S, Mimura J, Kawabe Y, Hosoya T, Morita M et al. 2008 Krüppel-like factor 5 is essential for blastocyst development and the normal self-renewal of mouse ESCs. Cell Stem Cell 3 555-567. (doi:10.1016/j.stem.2008.09.003)

Feinberg MW, Cao Z, Wara AK, Lebedeva MA, Senbanerjee S \& Jain MK 2005 Krüppel-like factor 4 is a mediator of proinflammatory signaling in macrophages. Journal of Biological Chemistry 280 38247-38258. (doi:10.1074/jbc.M509378200)

Figueira PG, Abrão MS, Krikun G \& Taylor HS 2011 Stem cells in endometrium and their role in the pathogenesis of endometriosis. Annals of the New York Academy of Sciences 1221 10-17. (doi:10.1111/ j.1749-6632.2011.05969.x)

Frigo DE, Sherk AB, Wittmann BM, Norris JD, Wang Q, Joseph JD, Toner AP, Brown M \& McDonnell DP 2009 Induction of Krüppel-like factor 5 expression by androgens results in increased CXCR4-dependent migration of prostate cancer cells in vitro. Molecular Endocrinology 23 1385-1396. (doi:10.1210/me.2009-0010)

Funnell AP, Mak KS, Twine NA, Pelka GJ, Norton LJ, Radziewic T, Power M, Wilkins MR, Bell-Anderson KS, Fraser ST et al. 2013 Generation of mice deficient in both KLF3/BKLF and KLF8 reveals a genetic interaction and a role for these factors in embryonic globin gene silencing. Molecular and Cellular Biology 33 2976-2987. (doi:10.1128/MCB.00074-13)

Groeneweg JW, Hall TR, Zhang L, Kim M, Byron VF, Tambouret R, Sathayanrayanan S, Foster R, Rueda BR \& Growdon WB 2014 Inhibition of $\gamma$-secretase activity impedes uterine serous carcinoma growth in a human xenograft model. Gynecologic Oncology 133 607-615. (doi:10.1016/j.ygyno.2014.03.560)

Guo W, Li P, Zhao G, Fan H, Hu Y \& Hou Y 2012 Glucocorticoid receptor mediates the effect of progesterone on uterine natural killer cells. American Journal of Reproductive Immunology 67 463-473. (doi:10.1111/ j.1600-0897.2012.01114.x)

Hall J, Guo G, Wray J, Eyres I, Nichols J, Grotewold L, Morfopoulou S, Humphreys P, Mansfield W, Walker R et al. 2009 Oct4 and LIF/Stat3 additively induce Krüppel factors to sustain embryonic stem cell selfrenewal. Cell Stem Cell 5 597-609. (doi:10.1016/j.stem.2009.11.003)

Hamilton KJ, Arao Y \& Korach KS 2014 Estrogen hormone physiology: reproductive findings from estrogen receptor mutant mice. Reproductive Biology 14 3-8. (doi:10.1016/j.repbio.2013.12.002)

He HJ, Gu XF, Xu WH, Yang DJ, Wang XM \& Su Y 2013 Krüppel-like factor 8 is a novel androgen receptor co-activator in human prostate cancer. Acta Pharmacologica Sinica 34 282-288. (doi:10.1038/aps.2012.130)

Heard ME, Pabona JM, Clayberger C, Krensky AM, Simmen FA \& Simmen RC 2012 The reproductive phenotype of mice null for transcription factor
Krüppel-like factor 13 suggests compensatory function of family member Krüppel-like factor 9 in the peri-implantation uterus. Biology of Reproduction 87 115. (doi:10.1095/biolreprod.112.102251)

Heard ME, Simmons CD, Simmen FA \& Simmen RC 2014 Krüppel-like factor 9 deficiency in uterine endometrial cells promotes ectopic lesion establishment associated with activated notch and hedgehog signaling in a mouse model of endometriosis. Endocrinology 155 1532-1546. (doi:10.1210/en.2013-1947)

Huang Y, Ju B, Tian J, Liu F, Yu H, Xiao H, Liu X, Liu W, Yao Z \& Hao Q 2014 Ovarian cancer stem cell-specific gene expression profiling and targeted drug prescreening. Oncology Reports 31 1235-1248. (doi:10.3892/or. 2014.2976)

Hubbard SA, Friel AM, Kumar B, Zhang L, Rueda BR \& Gargett CE 2009 Evidence for cancer stem cells in human endometrial carcinoma. Cancer Research 69 8241-8248. (doi:10.1158/0008-5472.CAN-08-4808)

Iizuka K, Takeda J \& Horikawa Y 2011 Krüppel-like factor-10 is directly regulated by carbohydrate response element-binding protein in rat primary hepatocytes. Biochemical and Biophysical Research Communications 412 638-643. (doi:10.1016/j.bbrc.2011.08.016)

Jiang J, Chan YS, Loh YH, Cai J, Tong GQ, Lim CA, Robson P, Zhong S \& $\mathrm{Ng}$ HH 2008 A core Klf circuitry regulates self-renewal of embryonic stem cells. Nature Cell Biology 10 353-360. (doi:10.1038/ncb1698)

Kaczynski J, Cook T \& Urrutia R 2003 Sp1- and Krüppel-like transcription factors. Genome Biology 4 206. (doi:10.1186/gb-2003-4-2-206)

Kavandi L, Collier MA, Nguyen H \& Syed V 2012 Progesterone and calcitriol attenuate inflammatory cytokines CXCL1 and CXCL2 in ovarian and endometrial cancer cells. Journal of Cellular Biochemistry $\mathbf{1 1 3}$ 3143-3152. (doi:10.1002/jcb.24191)

Kim JJ, Kurita T \& Bulun SE 2013 Progesterone action in endometrial cancer, endometriosis, uterine fibroids, and breast cancer. Endocrine Reviews 34 130-162. (doi:10.1210/er.2012-1043)

Knoedler JR \& Denver RJ 2014 Krüppel-like factors are effectors of nuclear receptor signaling. General and Comparative Endocrinology 203 49-59. (doi:10.1016/j.ygcen.2014.03.003)

Korani M, Fallah S, Tehranian A, Nourbakhsh M, Samadikuchaksaraei A, Pour MS \& Maleki J 2013 The evaluation of the FOXO1, KLF9 and YT521 genes expression in human endometrial cancer. Clinical Laboratory 59 483-489. (doi:10.7754/Clin.Lab.2012.120626)

Krikun G, Mor G, Alvero A, Guller S, Schatz F, Sapi E, Rahman M, Caze R, Qumsiyeh M \& Lockwood CJ 2004 A novel immortalized human endometrial stromal cell line with normal progestational response. Endocrinology 145 2291-2296. (doi:10.1210/en.2003-1606)

Laub F, Dragomir C \& Ramirez F 2006 Mice without transcription factor KLF7 provide new insight into olfactory bulb development. Brain Research 1103 108-113. (doi:10.1016/j.brainres.2006.05.065)

Lee B, Du H \& Taylor HS 2008 Experimental murine endometriosis induces DNA methylation and altered gene expression in eutopic endometrium. Biology of Reproduction 80 79-85. (doi:10.1095/biolreprod.108.070391)

Lei K, Chen L, Georgiou EX, Sooranna SR, Khanjani S, Brosens JJ, Bennett PR \& Johnson MR 2012 Progesterone acts via the nuclear glucocorticoid receptor to suppress IL-1 $\beta$-induced COX-2 expression in human term myometrial cells. PLoS ONE 7 e50167. (doi:10.1371/journal.pone.0050167)

Leow CC, Wang BE, Ross J, Chan SM, Zha J, Carano RA, Frantz G, Shen MM, de Sauvage FJ \& Gao WQ 2009 Prostate-specific Klf6 inactivation impairs anterior prostate branching morphogenesis through increased activation of the Shh pathway. Journal of Biological Chemistry $\mathbf{2 8 4}$ 21057-21065. (doi:10.1074/jbc.M109.001776)

Li T, He H, Liu R, Wang SX \& Pu DM 2014 Isolation and identification of epithelial and stromal stem cells from eutopic endometrium of women with endometriosis. European Journal of Obstetrics, Gynecology, and Reproductive Biology 178 89-94. (doi:10.1016/j.ejogrb.2014.04.001)

Limame R, Op de Beeck K, Lardon F, De Wever O \& Pauwels P 2014 Krüppel-like factors in cancer progression: three fingers on the steering wheel. Oncotarget 5 29-48.

Liu X, Gomez-Pinillos A, Loder C, Carrillo-de Santa Pau E, Qiao R, Unger PD, Kurek R, Oddoux C, Melamed J, Gallagher RE et al. 2012 KLF6 loss of 
function in human prostate cancer progression is implicated in resistance to androgen deprivation. American Journal of Pathology $\mathbf{1 8 1}$ 1007-1016. (doi:10.1016/j.ajpath.2012.06.008)

Lu H, Wang X, Urvalek AM, Li T, Xie H, Yu L \& Zhao J 2012 Transformation of human ovarian surface epithelial cells by Krüppel-like factor 8 . Oncogene 33 10-18. (doi:10.1038/onc.2012.545)

Marrero-Rodríguez D, Taniguchi-Ponciano K, Jimenez-Vega F, RomeroMorelos P, Mendoza-Rodríguez M, Mantilla A, Rodriguez-Esquivel M, Hernandez D, Hernandez A, Gomez-Gutierrez G et al. 2014 Krüppel-like factor 5 as potential molecular marker in cervical cancer and the KLF family profile expression. Tumour Biology 35 11399-11407. (doi:10.1007/s13277-014-2380-4)

Matsumoto N, Kubo A, Liu H, Akita K, Laub F, Ramirez F, Keller G \& Friedman SL 2006 Developmental regulation of yolk sac hematopoiesis by Krüppel-like factor 6. Blood 107 1357-1365. (doi:10.1182/blood2005-05-1916)

Mazella J, Liang S \& Tseng L 2008 Expression of Delta-like protein 4 in the human endometrium. Endocrinology 149 15-19. (doi:10.1210/ en.2007-0477)

Narla G, Heath KE, Reeves HL, Li D, Giono LE, Kimmelman AC, Glucksman MJ, Narla J, Eng FJ, Chan AM et al. 2001 KLF6, a candidate tumor suppressor gene mutated in prostate cancer. Science 294 2563-2566. (doi:10.1126/ science.1066326)

Natesampillai S, Kerkvliet J, Leung PC \& Veldhuis JD 2008 Regulation of Krüppel-like factor 4, 9, and 13 genes and the steroidogenic genes LDLR, StAR, and CYP11A in ovarian granulosa cells. American Journal of Physiology. Endocrinology and Metabolism 294 E385-E391. (doi:10.1152/ ajpendo.00480.2007)

Nelson SM, Telfer EE \& Anderson RA 2013 The ageing ovary and uterus: new biological insights. Human Reproduction Update 19 67-83. (doi:10.1093/humupd/dms043)

Oktem G, Bilir A, Uslu R, Inan SV, Demiray SB, Atmaca H, Ayla S, Sercan O \& Uysal A 2014 Expression profiling of stem cell signaling alters with spheroid formation in CD133 ${ }^{\text {high }} / \mathrm{CD} 44^{\text {high }}$ prostate cancer stem cells. Oncology Letters 72 103-109. (doi:10.3892/ol.2014.1992)

Ono M, Qiang W, Serna VA, Yin P, Coon JS, Navarro A, Monsivais D, Kakinuma T, Dyson M, Druschitz S et al. 2012 Role of stem cells in human uterine leiomyoma growth. PLoS ONE 7 e36935. (doi:10.1371/ journal.pone.0036935)

Ono M, Yin P, Navarro A, Moravek MB, Coon JS, Druschitz SA, Serna VA, Qiang W, Brooks DC, Malpani SS et al. 2013 Paracrine activation of $\mathrm{WNT} / \beta$-catenin pathway in uterine leiomyoma stem cells promotes tumor growth. PNAS 110 17053-17058. (doi:10.1073/pnas.1313650110)

Ono M, Bulun SE \& Maruyama T 2014 Tissue-specific stem cells in the myometrium andtumor-initiating cells in leiomyoma. Biology of Reproduction 91 149. (doi:10.1095/biolreprod.114.123794)

Pabona JM, Zeng Z, Simmen FA \& Simmen RC 2010 Functional differentiation of uterine stromal cells involves cross-regulation between bone morphogenetic protein 2 and Krüppel-like factor (KLF) female family members KLF9 and KLF13. Endocrinology 151 3396-3406. (doi:10.1210/en.2009-1370)

Pabona JM, Simmen FA, Nikiforov MA, Zhuang D, Shankar K, Velarde MC, Zelenco Z, Giudice LC \& Simmen RC 2012 Krüppel-like factor 9 and progesterone receptor coregulation of decidualizing endometrial stromal cells: implications for the pathogenesis of endometriosis. Journal of Clinical Endocrinology and Metabolism 97 376-392. (doi:10.1210/jc.2011-2562)

Pabona JM, Zhang D, Ginsburg DS, Simmen FA \& Simmen RC 2015 Prolonged pregnancy in women is associated with attenuated myometrial expression of progesterone receptor co-regulator Krüppel-like factor 9. Journal of Clinical Endocrinology and Metabolism $\mathbf{1 0 0}$ 166-174. (doi:10.1210/jc.2014-2846)

Pei J \& Grishin NV 2013 A new family of predicted Krüppel-like factor genes and pseudogenes in placental mammals. PLOS ONE 8 e81109. (doi:10.1371/journal.pone.0081109)
Rackow BW \& Taylor HS 2010 Submucosal uterine leiomyomas have a global effect on molecular determinants of endometrial receptivity. Fertility and Sterility 93 2027-2034. (doi:10.1016/j.fertnstert.2008. 03.029)

Ray S \& Pollard JW 2012 KLF15 negatively regulates estrogen-induced epithelial cell proliferation by inhibition of DNA replication licensing. PNAS 109 1334-1343. (doi:10.1073/pnas.1118515109)

Rosario GX, Hondo E, Jeong JW, Mutalif R, Ye X, Yee LX \& Stewart CL 2014 The LIF-mediated molecular signature regulating murine embryo implantation. Biology of Reproduction 91 66. (doi:10.1095/biolreprod. 114.118513)

Sakr S, Naqvi H, Komm B \& Taylor HS 2014 Endometriosis impairs bone marrow-derived stem cell recruitment to the uterus whereas bazedoxifene treatment leads to endometriosis regression and improved uterine stem cell engraftment. Endocrinology 155 1489-1497. (doi:10.1210/en. 2013-1977)

Sasson IE \& Taylor HS 2008 Stem cells and the pathogenesis of endometriosis. Annals of the New York Academy of Sciences 11 27106-27115. (doi:10.1196/ annals.1434.014)

Shen X, Hu Y, Jiang Y, Liu H, Zhu L, Jin X, Shan H, Zhen X, Sun L, Yan G et al. 2013 Krüppel-like factor 12 negatively regulates human endometrial stromal cell decidualization. Biochemical and Biophysical Research Communications 433 11-17. (doi:10.1016/j.bbrc.2013.02.078)

Shen P, Sun J, Xu G, Zhang L, Yang Z, Xia S, Wang Y, Liu Y \& Shi G 2014 KLF9, a transcription factor induced in flutamide-caused cell apoptosis, inhibits AKT activation and suppresses tumor growth of prostate cancer cells. Prostate 74 946-958. (doi:10.1002/pros.22812)

Shimizu Y, Takeuchi T, Mita S, Notsu T, Mizuguchi K \& Kyo S 2010 Krüppellike factor 4 mediates anti-proliferative effects of progesterone with $\mathrm{G}_{0} / \mathrm{G}_{1}$ arrest in human endometrial epithelial cells. Journal of Endocrinological Investigation 33 745-750. (doi:10.1007/BF03346681)

Simmen RC, Eason RR, McQuown JR, Linz AL, Kang TJ, Chatman L Jr, Till SR, Fujii-Kuriyama Y, Simmen FA \& Oh SP 2004 Subfertility, uterine hypoplasia, and partial progesterone resistance in mice lacking the Krüppel-like factor 9/basic transcription element-binding protein-1 (Bteb1) gene. Journal of Biological Chemistry 279 29286-29294. (doi:10.1074/jbc.M403139200)

Simmen FA, Su Y, Xiao R, Zeng Z \& Simmen RC 2008 The Krüppel-like factor 9 (KLF9) network in HEC-1-A endometrial carcinoma cells suggests the carcinogenic potential of dys-regulated KLF9 expression. Reproductive Biology and Endocrinology 6 41. (doi:10.1186/1477-7827-6-41)

Simmons C, Pabona JM, Heard ME, Friedman TM, Spataro MT, Godley AL, Simmen FA, Burnett AF \& Simmen RC 2011 Krüppel-like factor 9 loss-of-expression in human endometrial carcinoma links altered expression of growth-regulatory genes and aberrant proliferative response to estrogen. Biology of Reproduction 85 378-385. (doi:10.1095/ biolreprod.110.090654)

Simon L, Spiewak KA, Ekman GC, Kim J, Lydon JP, Bagchi MK, Bagchi IC, DeMayo FJ \& Cooke PS 2009 Stromal progesterone receptors mediate induction of Indian Hedgehog $(\mathrm{IHH})$ in uterine epithelium and its downstream targets in uterine stroma. Endocrinology 150 3871-3876. (doi:10.1210/en.2008-1691)

Song CZ, Gavriilidis G, Asano H \& Stamatoyannopoulos G 2005 Functional study of transcription factor KLF11 by targeted gene inactivation. Blood Cells, Molecules \& Diseases 34 53-59. (doi:10.1016/j.bcmd.2004.08.027)

Spitzer TL, Rojas A, Zelenko Z, Aghajanova L, Erikson DW, Barragan F, Meyer M, Tamaresis JS, Hamilton AE, Irwin JC et al. 2012 Perivascular human endometrial mesenchymal stem cells express pathways relevant to self-renewal, lineage specification, and functional phenotype. Biology of Reproduction 86 58. (doi:10.1095/biolreprod.111.095885)

Sun X, Zhang L, Xie H, Wan H, Magella B, Whitsett JA \& Dey SK 2012 Krüppel-like factor 5 (KLF5) is critical for conferring uterine receptivity to implantation. PNAS 109 1145-1150. (doi:10.1073/pnas.1118411109)

Suske G, Bruford E \& Philipsen S 2005 Mammalian SP/KLF transcription factors: bring in the family. Genomics 85 551-556. (doi:10.1016/ j.ygeno.2005.01.005) 
Tamaresis JS, Irwin JC, Goldfien GA, Rabban JT, Burney RO, Nezhat C, DePaolo LV \& Giudice LC 2014 Molecular classification of endometriosis and disease stage using high-dimensional genomic data. Endocrinology 155 4986-4999. (doi:10.1210/en.2014-1490)

Tetreault MP, Alrabaa R, McGeehan M \& Katz JP 2012 Krüppel-like factor 5 protects against murine colitis and activates JAK-STAT signaling in vivo. PLOS ONE 7 e38338. (doi:10.1371/journal.pone.0038338)

Tetreault MP, Yang Y \& Katz JP 2013 Krüppel-like factors in cancer. Nature Reviews. Cancer 13 701-713. (doi:10.1038/nrc3582)

Velarde MC, Geng Y, Eason RR, Simmen FA \& Simmen RC 2005 Null mutation of Krüppel-like factor 9/basic transcription element binding protein-1 alters peri-implantation uterine development in mice. Biology of Reproduction 73 472-481. (doi:10.1095/biolreprod.105.041855)

Velarde MC, Zeng Z, McQuown JR, Simmen FA \& Simmen RC 2007 Krüppellike factor 9 is a negative regulator of ligand-dependent estrogen receptor $\alpha$ signaling in Ishikawa endometrial adenocarcinoma cells. Molecular Endocrinology 21 2988-3001. (doi:10.1210/me.2007-0242)

Wang Y, Michel FJ, Wing A, Simmen FA \& Simmen RC 1997 Cell-type expression, immunolocalization, and deoxyribonucleic acid-binding activity of basic transcription element binding transcription factor, an Sp-related family member, in porcine endometrium of pregnancy. Biology of Reproduction 57 707-714. (doi:10.1095/biolreprod57.4.707)

Wang F, Zhu Y, Huang Y, McAvoy S, Johnson WB, Cheung TH, Chung TK, Lo KW, Yim SF, Yu MM et al. 2005 Transcriptional repression of WEE1 by Krüppel-like factor 2 is involved in DNA damage-induced apoptosis. Oncogene 24 3875-3885. (doi:10.1038/sj.onc.1208546)

Wang J, Place RF, Huang V, Wang X, Noonan EJ, Magyar CE, Huang J \& Li LC 2010 Prognostic value and function of KLF4 in prostate cancer: RNAi and vector-mediated overexpression identify KLF4 as an inhibitor of tumor cell growth and migration. Cancer Research 70 10182-10191. (doi:10.1158/0008-5472.CAN-10-2414)

Wani MA, Wert SE \& Lingrel JB 1999 Lung Krüppel-like factor, a zinc finger transcription factor, is essential for normal lung development. Journal of Biological Chemistry 274 21180-21185. (doi:10.1074/jbc.274. 30.21180)

Yang WT \& Zheng PS 2014 Promoter hypermethylation of KLF4 inactivates its tumor suppressor function in cervical carcinogenesis. PLOS ONE 9 e88827. (doi:10.1371/journal.pone.0088827)

Yin P, Lin Z, Reierstad S, Wu J, Ishikawa H, Marsh EE, Innes J, Cheng Y, Pearson K, Coon JS IV et al. 2010 Transcription factor KLF11 integrates progesterone receptor signaling and proliferation in uterine leiomyoma cells. Cancer Research 70 1722-1730. (doi:10.1158/00085472.CAN-09-2612)

Ying M, Sang Y, Li Y, Guerrero-Cazares H, Quinones-Hinojosa A, Vescovi AL, Eberhart CG, Xia S \& Laterra J 2011 Krüppel-like family of transcription factor 9, a differentiation-associated transcription factor, suppresses Notch1 signaling and inhibits glioblastoma-initiating stem cells. Stem Cells 29 20-31. (doi:10.1002/stem.561)
Ying M, Tilghman J, Wei Y, Guerrero-Cazares H, Quinones-Hinojosa A, Ji H \& Laterra J 2014 KLF9 inhibits glioblastoma stemness through global transcription repression and integrin- $\alpha 6$ inhibition. Journal of Biological Chemistry 289 32742-32756. (doi:10.1074/jbc.M114.588988)

Yoon O \& Roh J 2012 Downregulation of KLF4 and the Bcl-2/Bax ratio in advanced epithelial ovarian cancer. Oncology Letters 4 1033-1036. (doi:10.3892/ol.2012.834)

Yusuf I, Kharas MG, Chen J, Peralta RQ, Maruniak A, Sareen P, Yang VW, Kaestner KH \& Fruman DA 2008 KLF4 is a FOXO target gene that suppresses B cell proliferation. International Immunology 20 671-681. (doi:10.1093/intimm/dxn024)

Zeng Z, Velarde MC, Simmen FA \& Simmen RC 2008 Delayed parturition and altered myometrial progesterone receptor isoform A expression in mice null for Krüppel-like factor 9. Biology of Reproduction $\mathbf{7 8}$ 1029-1037. (doi:10.1095/biolreprod.107.065821)

Zhang D, Zhang XL, Michel FJ, Blum JL, Simmen FA \& Simmen RC 2002 Direct interaction of the Krüppel-like family (KLF) member, BTEB1 and PR mediates progesterone-responsive gene expression in endometrial epithelial cells. Endocrinology 143 62-73. (doi:10.1210/endo.143.1. 8590)

Zhang XL, Michel FJ, Blum JL, Simmen FA \& Simmen RC 2003 Selective interactions of Krüppel-like factor 9/basic transcription elementbinding protein with progesterone receptor isoforms A and B determine transcriptional activity of progesterone-responsive genes in endometrial epithelial cells. Journal of Biological Chemistry 278 21474-21482. (doi:10.1074/jbc.M212098200)

Zhang Y, Lam O, Nguyen MT, Ng G, Pear WS, Ai W, Wang IJ, Kao WW \& Liu CY 2013 Mastermind-like transcriptional co-activator-mediated Notch signaling is indispensable for maintaining conjunctival epithelial identity. Development 140 594-605. (doi:10.1242/dev.082842)

Zhang QH, Dou HT, Tang YJ, Su S \& Liu PS 2014a Lentivirus-mediated knockdown of Krüppel-like factor 9 inhibits the growth of ovarian cancer. Archives of Gynecology and Obstetrics 291 377-382. (doi:10.1007/ s00404-014-3405-3)

Zhang Y, Lei CQ, Hu YH, Xia T, Li M, Zhong B \& Shu HB 2014b Krüppel-like factor 6 is a co-activator of NF- $\kappa \mathrm{B}$ that mediates p65-dependent transcription of selected downstream genes. Journal of Biological Chemistry 289 12876-12885. (doi:10.1074/jbc.M113.535831)

Zheng H, Pritchard DM, Yang X, Bennett E, Liu G, Liu C \& Ai W 2009 KLF4 gene expression is inhibited by the notch signaling pathway that controls goblet cell differentiation in mouse gastrointestinal tract. American Journal of Physiology. Gastrointestinal and Liver Physiology 296 G490-G498. (doi:10.1152/ajpgi.90393.2008)

Zheng Y, Tabbaa ZM, Khan Z, Schoolmeester JK, El-Nashar S, Famuyide A, Keeney GL \& Daftary GS 2014 Epigenetic regulation of uterine biology by transcription factor KLF11 via posttranslational histone deacetylation of cytochrome p450 metabolic enzymes. Endocrinology 155 4507-4520. (doi:10.1210/en.2014-1139)

Received in final form 20 January 2015

Accepted 4 February 2015 http://jme.endocrinology-journals.org

DOI: 10.1530/JME-14-0310
(C) 2015 Society for Endocrinology Printed in Great Britain
Published by Bioscientifica Ltd. 